\title{
First Occurrence of Chain Pickerel (Esox niger) in Ontario: Possible Range Expansion from New York Waters of Eastern Lake Ontario
}

\author{
JAMES A. HoYle ${ }^{1}$ and COLIN LAKE ${ }^{1}$ \\ ${ }^{1}$ Ontario Ministry of Natural Resources, Glenora Fisheries Station, 41 Hatchery Lane, Picton, Ontario K0K 2T0 Canada \\ Hoyle, James A., and Colin Lake. 2011. First occurrence of Chain Pickerel (Esox niger) in Ontario: possible range expansion \\ from New York waters of eastern Lake Ontario. Canadian Field-Naturalist 125(1): 16-21. \\ In this paper, we document the first Chain Pickerel (Esox niger) collected in Ontario and the first on the northwestern side \\ of the St. Lawrence River in Canada. The fish was caught by a local commercial fisherman in April 2008. Since 2008, five \\ additional specimens have been caught and are also documented here: three in 2009 and two more through spring 2010 . All \\ individuals were mature adults in robust condition. The appearance of Chain Pickerel in the Ontario waters of eastern Lake \\ Ontario and the upper St. Lawrence River may signal an expansion in the range of this species from New York state waters.
}

Key Words: Esox niger, Chain Pickerel, range expansion, Ontario, Lake Ontario, St. Lawrence River.

The Chain Pickerel (Esox niger) is a small to medium-sized member of the pike family (Esocidae). The species prefers warm water, usually inhabits sluggish streams and heavily vegetated lakes, and is a top predator in the fish community (Scott and Crossman 1973). Its native range is primarily the Atlantic coastal plain on the east side of the Allegheny-Appalachian Mountains in the eastern United States. Introductions and range expansions have resulted in a distribution that now extends west of the Allegheny-Appalachian Mountains (Coffie 1998).

The Canadian distribution of the Chain Pickerel includes Quebec (south of the St. Lawrence River and east of Montreal), southern New Brunswick, and Nova Scotia. Its status is Not at Risk in Canada (COSEWIC 1997*; Coffie 1998). The species is not native to New Brunswick or Nova Scotia, and its native status in Quebec seems uncertain (Coffie 1998). Previous reports of Chain Pickerel in Canadian waters of Lake Ontario are considered by Scott and Crossman (1973); and Coffie (1998) to be in error. The historical observation in question was made in 1908, and no confirmed observations of this species have been documented until now. In this paper, we document the first occurrence of Chain Pickerel in Canadian waters of eastern Lake Ontario and the upper St. Lawrence River.

\section{Chronology and Locations of Occurrences}

The following chronology documents the occurrences of six Chain Pickerel captured between 25 April 2008 and 10 May 2010 and submitted to the Glenora Fisheries Station of the Ontario Ministry of Natural Resources in Picton, Ontario. Detailed capture, biological and morphometric, and meristic information for these fish is reported in Table 1. Six additional anecdotal reports (fish not physically examined by the authors) are also noted (Table 2). These occurrences represent the first documented Chain Pickerel records in the province of Ontario.

\section{Fish 1}

On 25 April 2008, a commercial fisher caught an "unusual pike" while fishing for Yellow Perch (Perca flavescens) with gill net gear (57-mm mesh size) near the mouth of Parrotts Bay in the lower Bay of Quinte, Lake Ontario (Figure 1). The fish was submitted (frozen) to the Glenora Fisheries Station on 28 April 2008. The golden, chain-like markings on the flanks of the fish (Figure 2) suggested that the fish was a Chain Pickerel, and this was confirmed by submandibular pore count of 8 (4 on each side), branchiostegal ray counts of $6+8$ (total 14 , ceratohyal + epihyal) on the left side and $6+9(15)$ on the right side, and prominent vertical subocular bars (Holm et al. 2009). Upper and lower halves of both cheeks and opercula were fully scaled.

The fish appeared to have a fresh Sea Lamprey (Petromyzon marinus) wound (skin not broken, diameter of wound 18-20 mm) on the right side just above the pelvic fin. The first fish was not examined internally, but eggs running freely from the body after partial thawing indicated that it was a mature female. These eggs were counted $(n=724)$ and weighed $(4.48 \mathrm{~g})$, and an estimate of fecundity thus determined (Table 1). Also caught in the same gill net were Yellow Perch, White Sucker (Catostomus commersoni), Northern Pike (Esox lucius), Rock Bass (Ambloplites rupestris), Longnose Gar (Lepisosteus osseus), and Walleye (Sander vitreus). This was the first Chain Pickerel observed at the Glenora Fisheries Station, which has been monitoring the local fish community and fisheries since the $1950 \mathrm{~s}$.

\section{Fish 2}

On 16 September 2009, a single Chain Pickerel was caught near Wolfe Island during a routine fish community index gill netting survey in the Thousand Islands area of the upper St. Lawrence River. This survey has been conducted biennially by Ontario Ministry of Natural Resources staff since 1987. The fish was caught 
TABLE 1. Vital statistics for six Chain Pickerel (Esox niger) from Canadian waters of the eastern Lake Ontario/upper St. Lawrence River region. The first two fish were subsequently delivered to the Royal Ontario Museum (ROM catalogue numbers indicated). All fish were mature; the degree of gonad development is indicated. Capture locations are illustrated in Figure 1.

\begin{tabular}{|c|c|c|c|c|c|c|}
\hline & \multicolumn{6}{|c|}{ Fish } \\
\hline & 1 & 2 & 3 & 4 & 5 & 6 \\
\hline Source & $\begin{array}{l}\text { commercial } \\
\text { fisher }\end{array}$ & $\begin{array}{c}\text { Ministry of } \\
\text { Natural Resources }\end{array}$ & $\begin{array}{l}\text { commercial } \\
\text { fisher }\end{array}$ & $\begin{array}{l}\text { commercial } \\
\text { fisher }\end{array}$ & $\begin{array}{l}\text { commercial } \\
\text { fisher }\end{array}$ & $\begin{array}{l}\text { commercial } \\
\text { fisher }\end{array}$ \\
\hline Gear & gill net & gill net & hoop net & hoop net & hoop net & hoop net \\
\hline Latitude & 44.208 & 44.234 & 44.198 & 44.198 & 44.187 & 44.187 \\
\hline Longitude & -76.698 & -76.283 & -76.368 & -76.368 & -76.625 & -76.625 \\
\hline Date of capture & $\begin{array}{l}25 \text { April } \\
2008\end{array}$ & $\begin{array}{l}16 \text { September } \\
2009\end{array}$ & $\begin{array}{l}\text { 2-12 April } \\
2009\end{array}$ & $\begin{array}{l}\text { 2-12 April } \\
2009\end{array}$ & $\begin{array}{l}30 \text { April } \\
2010\end{array}$ & $\begin{array}{l}10 \text { May } \\
2010\end{array}$ \\
\hline Date sampled & $\begin{array}{l}28 \text { April } \\
2008\end{array}$ & $\begin{array}{l}14 \text { October } \\
2009\end{array}$ & $\begin{array}{l}10 \text { March } \\
2010\end{array}$ & $\begin{array}{l}10 \text { March } \\
2010\end{array}$ & $\begin{array}{l}4 \text { May } \\
2010\end{array}$ & $\begin{array}{l}\text { 14 May } \\
2010\end{array}$ \\
\hline ROM catalogue no. & 86559 & 86560 & $\mathrm{n} / \mathrm{a}$ & $\mathrm{n} / \mathrm{a}$ & $\mathrm{n} / \mathrm{a}$ & $\mathrm{n} / \mathrm{a}$ \\
\hline Total length (mm) & 454 & 581 & 571 & 594 & 579 & 564 \\
\hline Fork length (mm) & 420 & 536 & 527 & 553 & 534 & 521 \\
\hline $\begin{array}{l}\text { Round weight (before } \\
\text { processing or removal }\end{array}$ & & & & & & \\
\hline of any part) (g) & 762 & 1465 & 1233 & 1169 & 1243 & 1138 \\
\hline Sex & female & male & male & male & male & male \\
\hline State of maturity & $\begin{array}{l}\text { ripe and } \\
\text { running }\end{array}$ & $\begin{array}{c}\text { gonad } \\
\text { developing }\end{array}$ & $\begin{array}{l}\text { gonad fully } \\
\text { developed }\end{array}$ & $\begin{array}{l}\text { gonad fully } \\
\text { developed }\end{array}$ & gonad spent & gonad spent \\
\hline Fecundity (eggs g ${ }^{-1}$ ) & 162 & - & - & - & - & - \\
\hline Submandibular pores & & & & & & \\
\hline Left & 4 & 5 & 4 & 4 & 4 & 4 \\
\hline Right & 4 & 4 & 4 & 4 & 4 & 4 \\
\hline Branchiostegal rays & & & & & & \\
\hline Left & 6,8 & 6,9 & 5,9 & 6,8 & 6,9 & 6,8 \\
\hline Right & 6,9 & 6,9 & 5,9 & 5,8 & 6,9 & 5,9 \\
\hline
\end{tabular}

TABLE 2. Anecdotal reports of captures of Chain Pickerel (Esox niger). Note that a photograph was provided with reports iii and vi. Round weights are approximate.

\begin{tabular}{|c|c|c|c|c|c|c|}
\hline & \multicolumn{6}{|c|}{ Report } \\
\hline & $\mathrm{i}$ & ii & iii & iv* & $\mathrm{v}$ & vi \\
\hline Source & $\begin{array}{l}\text { commercial } \\
\text { fisher }\end{array}$ & $\begin{array}{l}\text { commercial } \\
\text { fisher }\end{array}$ & $\begin{array}{l}\text { commercial } \\
\text { fisher }\end{array}$ & $\begin{array}{l}\text { commercial } \\
\text { fisher }\end{array}$ & $\begin{array}{l}\text { commercial } \\
\text { fisher }\end{array}$ & angler \\
\hline Gear & hoop net & hoop net & hoop net & hoop net & hoop net & $\begin{array}{c}\text { rod and } \\
\text { reel }\end{array}$ \\
\hline Latitude & 44.187 & 44.156 & 44.091 & 44.286 & 44.200 & 43.987 \\
\hline Longitude & -76.625 & -76.898 & -77.306 & -76.265 & -76.345 & -77.002 \\
\hline Date of capture & $\begin{array}{l}\text { Spring } \\
2009\end{array}$ & $\begin{array}{l}\text { March } \\
2010\end{array}$ & $\begin{array}{l}21 \text { March } \\
2010\end{array}$ & $\begin{array}{c}\text { March/April } \\
2010\end{array}$ & $\begin{array}{l}3 \text { May } \\
2010\end{array}$ & $\begin{array}{l}19 \text { June } \\
2010\end{array}$ \\
\hline $\begin{array}{l}\text { Photograph } \\
\text { provided }\end{array}$ & no & no & yes & no & no & yes \\
\hline $\begin{array}{l}\text { Round weight } \\
\text { (before processing } \\
\text { or removal of any } \\
\text { part) (g) }\end{array}$ & 1200 & 1200 & 1200 & $<75$ & 675 & 1200 \\
\hline Number of fish & 1 & 1 & 1 & $4-6$ & 1 & 1 \\
\hline
\end{tabular}

\footnotetext{
* Note: Fisher reported a total of 4-6 fish caught in the leader (1 3/4 inch mesh) of a hoop net in late March and early April.
} 


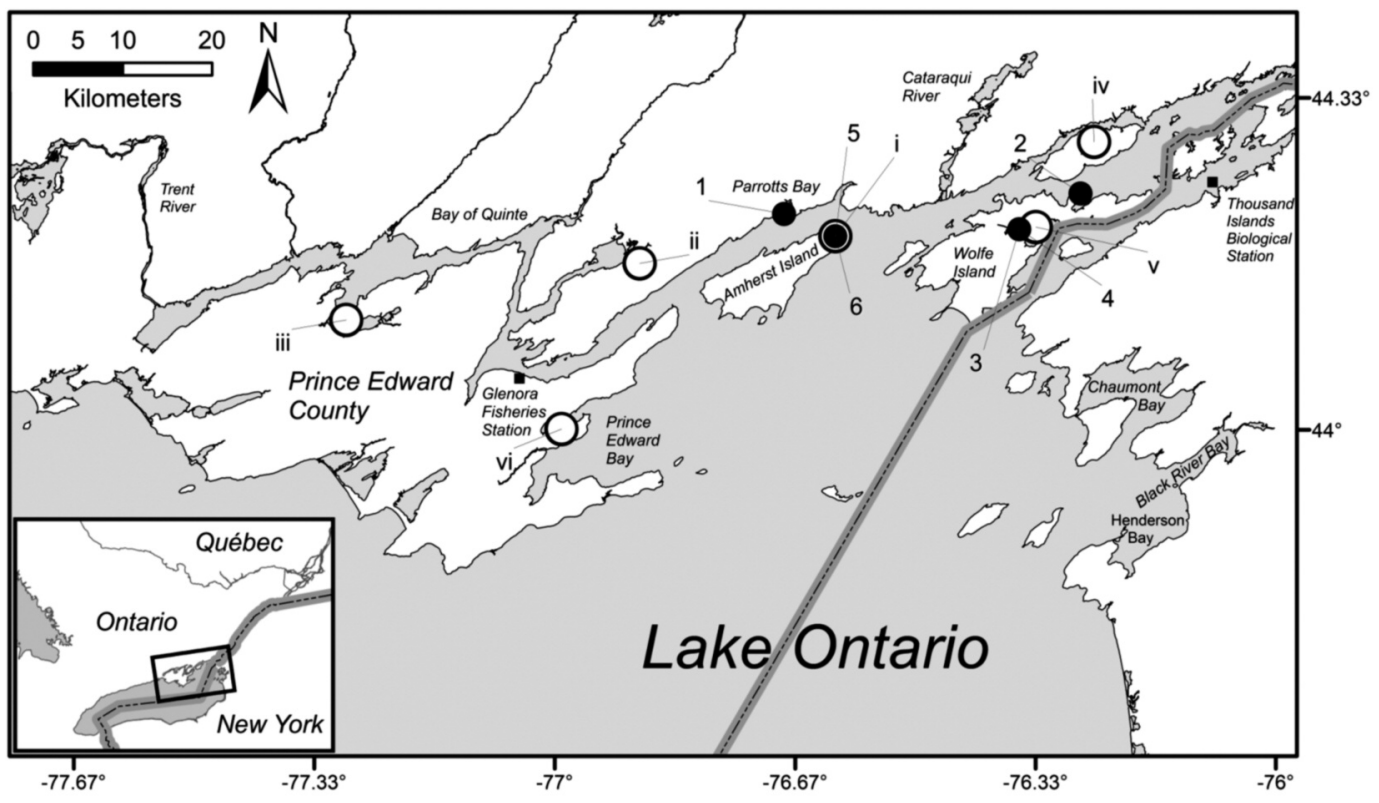

Figure 1. Map of eastern Lake Ontario and the upper St. Lawrence River showing occurrences of Chain Pickerel (Esox niger) $(1=$ confirmed, $\mathrm{i}=$ anecdotal $)$, as described in tables 1 and 2 . Note that anecdotal occurrences iii and vi included a photograph. The Glenora Fisheries Station (Ontario Ministry of Natural Resources) and the Thousand Islands Biological Station (State University of New York College of Environmental Science and Forestry) are also shown.

in the 102-mm mesh panel of a gang of gill net consisting of 10 mesh sizes ranging from 38 to $152 \mathrm{~mm}$ (approximately 13-mm intervals). Also caught in the same gill net gang were Yellow Perch, Brown Bullhead (Ameiurus nebulosus), Rock Bass, White Sucker, Northern Pike, and Largemouth Bass (Micropterus salmoides). The net was located in water $4.8 \mathrm{~m}$ deep, and the water temperature and secchi depth readings were $20.4^{\circ} \mathrm{C}$ and $5.0 \mathrm{~m}$, respectively.

\section{Fish 3 and 4}

On 9 March 2010, two Chain Pickerel that had been kept frozen for approximately one year since their original capture some time between 2 and 12 April 2009 were turned in by a local commercial fisher. The two fish had reportedly been caught on a single day, but it is not known whether they were caught in the same hoop net. The fish were submitted to staff at the Glenora Fisheries Station after a presentation by JAH alerted commercial fishers to the presence of Chain Pickerel in the area. Also caught during this same time period were Yellow Perch, Black Crappie (Pomoxis nigromaculatus), Northern Pike, sunfish (likely Pumpkinseed, Lepomis gibbosus), and White Perch (Morone americana).

\section{Fish 5 and 6}

These two Chain Pickerel were caught at the east end of Amherst Island by a local commercial fisher, the first on 30 April and the second on 10 May 2010.
The fish were caught on different dates but in the same hoop net set at the same location. Also caught with these Chain Pickerel were Brown Bullhead, American Eel (Anguilla rostrata), and redhorse (Moxostoma spp.).

\section{Other possible occurrences}

Anecdotal reports of additional Chain Pickerel have also been received: one in 2009 and five in 2010. Two of these reports included photographs of the fish. One of these reports involved the capture of multiple fish (a total of 4-6) over several weeks, while the remaining five reports involved single fish (Table 2). Three occurrences were from the same general area as the six fish documented above. The other three were distributed more widely to the west and north (Prince Edward Bay and Bay of Quinte, Lake Ontario) of the original occurrences.

Five of these six possible occurrences were reported taken by commercial hoop net fishers and one was reported taken by angling (Table 2 ). With the exception of the 4-6 small individuals (report number IV in Table 2), the size range of the fish was similar to the sizes of the six fish documented above (Table 1). Identification of juvenile esocids based on general appearance can be difficult because the colour pattern of juveniles is different from that of adults of the same species. The colour pattern of the juvenile Chain Pickerel is similar to the juvenile Northern Pike, but differs in having fully scaled gill covers and fewer than 10 


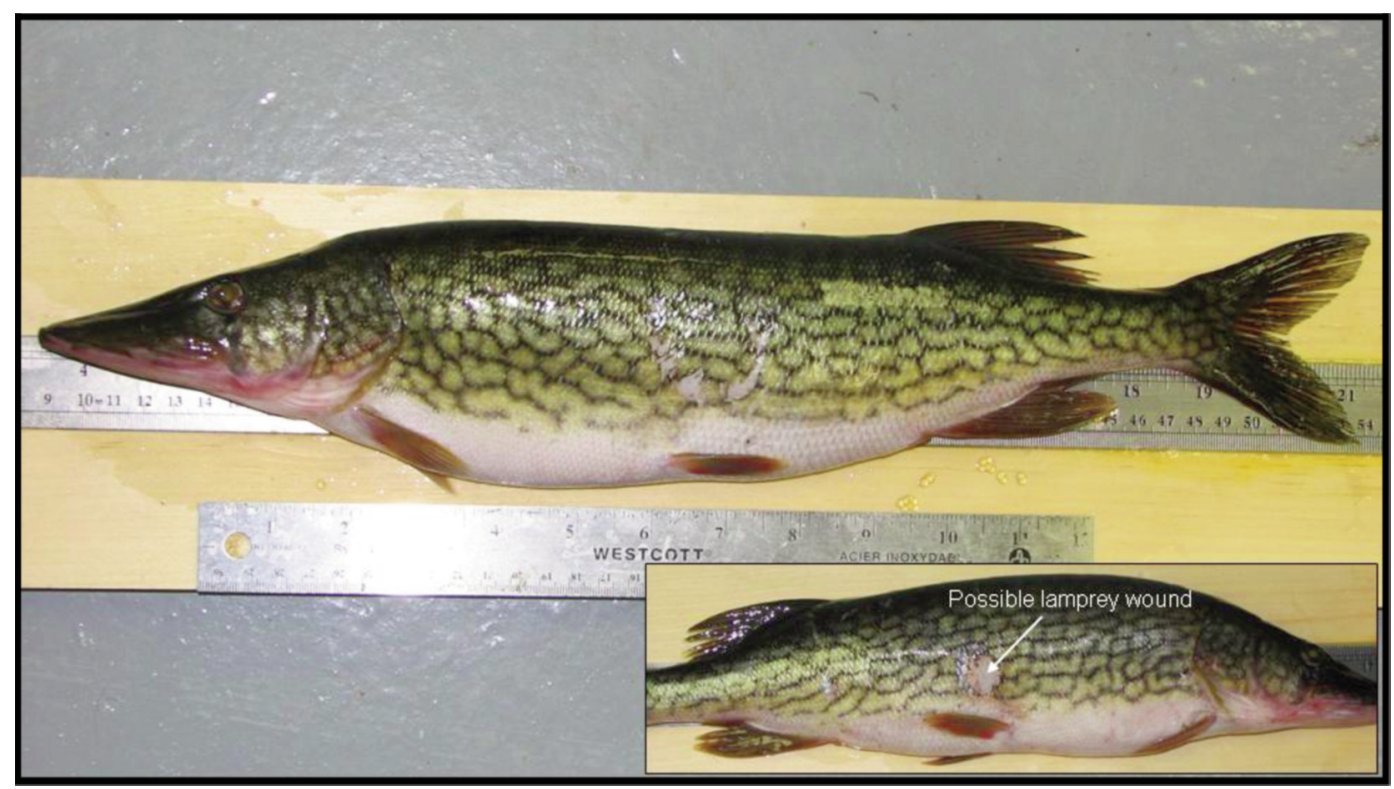

FiguRE 2. Photograph of the first documented Chain Pickerel (Esox niger) in the province of Ontario, caught on 25 April 2008 near Parrotts Bay, Lake Ontario (see Fish 1 in Table 1). Inset photo shows possible Sea Lamprey wound on the right side of the fish.

pores on the underside of the lower jaw. The juvenile Chain Pickerel differs from the juvenile Grass Pickerel (Esox americanus vermiculatus) and the juvenile Redfin Pickerel (E. a. americanus) in having 14-17 rays in each gill membrane (Holm et al. 2009). Although it is tempting to conclude that Chain Pickerel are now successfully reproducing in the area, additional confirmed observations of juvenile fish are required.

\section{Discussion}

Where did these Chain Pickerel come from? Coffie (1998) suggested that Chain Pickerel could potentially make their way west, from the Eastern Townships of Quebec, up the St. Lawrence River to Lake Ontario. Although Chain Pickerel records are common in the Eastern Townships, intensive fish surveys in the lower St. Lawrence River during the 1970s, 1990s, and 2000s revealed only two Chain Pickerel, possibly misidentified, in the St. Lawrence River proper, both below Montreal.

It seems very unlikely that a natural movement of the Chain Pickerel from the lower St. Lawrence River to the international sector has occurred to date (Pierre Dumont, Ministère des Resources naturelles et de la Faune du Québec, personal communication, 7 February 2011). Furthermore, extensive commercial and government index fishing throughout the Ontario waters of the St. Lawrence River did not reveal any Chain Pickerel prior to the present work (Ontario Ministry of Natural Resources, unpublished data). Similarly, exten- sive and long-term sampling by the New York State Department of Environmental Conservation and by the State University of New York (SUNY) College of Environmental Science and Forestry (Thousand Islands Biological Station) targeting adult and young-of-theyear esocids in New York waters of the upper St. Lawrence River has not yet shown any evidence of Chain Pickerel on the south side of the river to date (Farrell et al. 2007; New York State Department of Environmental Conservation 2010*; J. Farrell, SUNY College of Environmental Science and Forestry, personal communication, 3 February 2011).

In contrast, in the nearby New York waters of eastern Lake Ontario, Chain Pickerel abundance has increased in some areas (i.e., Chaumont Bay, Black River Bay, and Henderson Bay). Chain Pickerel have likely dispersed to these eastern Lake Ontario embayments from the upper reaches of the Black River basin, where the species is common (R. Klindt, New York State Department of Environmental Conservation, personal communication, 31 July 2010). Chain Pickerel are also common in Oneida Lake in the Finger Lakes area of New York State, and movement via the Oneida and Oswego rivers to southeastern Lake Ontario is also plausible (J. R. Jackson, Cornell University Biological Field Station, personal communication, 8 February 2011).

Given the present documented distribution of Chain Pickerel in Ontario waters, it seems most likely that the origin of this new Canadian population is the New 
York waters of eastern Lake Ontario. Genetics studies to investigate this hypothesized origin and to examine the degree of hybridization (e.g., with Northern Pike) would be beneficial (see Crossman and Buss 1965; Casselman et al. 1986).

Three other members of the esocid family are native to this area of Lake Ontario. Two, the Muskellunge (Esox masquinongy) and Northern Pike, are larger bodied than the Chain Pickerel, and one, the Grass Pickerel, has a smaller body than the Chain Pickerel. All are specialized top predators in the fish community. Northern Pike have shown long-term trends of decline in the Thousand Islands area of the upper St. Lawrence River (Ontario Ministry of Natural Resources 2010*) and New York waters of eastern Lake Ontario (New York State Department of Environmental Conservation 2010*). The upper St. Lawrence River Muskellunge population experienced significant die-offs in 2005 and 2006 related to viral hemorrhagic septicemia (VHS) (ScienceDaily 2007*). These events may have opened niche space for the invading Chain Pickerel. The Grass Pickerel also appears to be expanding its distribution and abundance (J. Farrell, SUNY College of Environmental Science and Forestry, personal communication, 3 February 2011).

The establishment of the Chain Pickerel in this area could have an impact on the other esocids and other piscivores in the fish community that have similar habitat requirements, such as Largemouth Bass. Ecosystem changes to eastern Lake Ontario (especially the Bay of Quinte) following the arrival of zebra and quagga mussels (Dreissena spp.), such as clearer water, more aquatic vegetation, and increased abundance of nearshore prey fish species (e.g., Pumpkinseed Sunfish and Bluegill Sunfish, Lepomis macrochirus), may favour these ambush, sight-feeding piscivores (Hoyle et al. in press).

The appearance of Chain Pickerel in the eastern Lake Ontario and upper St. Lawrence River region may signal a northwestern expansion of the species' range. Mandrak (1989) concluded that Chain Pickerel would invade Ontario from the south under a climate warming scenario. Indeed, Casselman (2002) reported a significant increase in water temperatures in eastern Lake Ontario and the Bay of Quinte over the last 50 years. The Chain Pickerel is adapted to warm water and heavily vegetated, nearshore habitats. For this reason, the St. Lawrence River and the vast open waters of Lake Ontario may represent somewhat of a physical barrier to the expansion of the Chain Pickerel from the south. Having now bridged this barrier, the species appears to be dispersing rather quickly in Ontario waters and it may now be relatively uninhibited in continuing its expansion north into Ontario via the Cataraqui River-Rideau Canal and Trent-Severn waterways, east down the St. Lawrence River, and west around Prince Edward County toward north-central Lake Ontario. Dispersal further west along the north shore of Lake Ontario may be more difficult because that shoreline is largely devoid of warm, vegetated waters. Presumably, continued range expansion to the north would eventually be limited by water temperature regime. Climate warming in this region of southern Ontario would potentially favour the persistence of Chain Pickerel at the northern edge of its expanded range.

\section{Acknowledgements}

Thanks to Cliff Young for bringing the first Chain Pickerel to our attention. Thanks to Dale Dewey, Dawn Walsh, and Mark Ebener for their expert comments regarding the possible Sea Lamprey wound on the first Chain Pickerel. Thanks also to Ross Abbett, Brian Bell, Lynn Bouvier, John Casselman, Andy Cook, Joanne and Kendall Dewey, Pierre Dumont, John Farrell, Erling Holm, Randy Jackson, Kevin Kayle, Rodger Klindt, Andre Laframboise, Steve Lapan, Rodney Lloyd, Scott MacLaren, Marc Mingelbier, Nick Mandrak, Jim McKenna, Tyson Scholz, Jim Sedore, Les Stanfield, and Barry Woodman. Thanks to the anonymous reviewers whose comments and suggestions were most constructive and encouraging.

Documents Cited (marked * in text)

Committee on the Status of Endangered Wildlife in Canada (COSEWIC). 1997. Retrieved February 3, 2011, from [http://www.sararegistry.gc.ca/species/speciesDetails_e.c fm?sid=315].

New York State Department of Environmental Conservation. 2010. New York State Department of Environmental Conservation 2009 Annual Report: Bureau of Fisheries Lake Ontario Unit and St. Lawrence River Unit to the Great Lake Fishery Commission's Lake Ontario Committee. New York State Department of Environmental Conservation, Cape Vincent, New York, U.S.A. http://www.dec.ny.gov/ outdoor/27068.html.

Ontario Ministry of Natural Resources. 2010. Lake Ontario Fish Communities and Fisheries: 2009 Annual Report of the Lake Ontario Management Unit. Ontario Ministry of Natural Resources, Picton, Ontario, Canada. http://www .glfc.org/lakecom/loc/mgmt_unit/index.html.

ScienceDaily. 2007. Muskellunge numbers drop as virus invades St. Lawrence River. Science News, July 25, 2007. Reprinted with editorial adaptations by ScienceDaily staff from materials provided by the State University of New York College of Environmental Science and Forestry. Retrieved February 3, 2011, from http://www.sciencedaily .com/releases/2007/07/070721201254.htm.

\section{Literature Cited}

Casselman, J. M. 2002. Effects of temperature, global extremes, and climate change on year-class production of warmwater, coolwater, and coldwater fishes in the Great Lakes basin. Pages 39-60 in Fisheries in a Changing Climate. Edited by N. A. McGinn. American Fisheries Society, Symposium 32, Bethesda, Maryland.

Casselman, J. M., E. J. Crossman, P. E. Ihssen, J. D. Reist, and H. E. Brooke. 1986. Identification of muskellunge, northern pike and their hybrids. American Fisheries Society Special Publication 15: 14-46. 
Crossman, E. J., and K. Buss. 1965. Hybridization in the family Esocidae. Journal of the Fisheries Research Board of Canada 22: 1261-1292.

Coffie, P. A. 1998. Status of the Chain Pickerel, Esox niger, in Canada. Canadian Field-Naturalist 112(1): 133-140.

Farrell, J. M., R. M. Klindt, J. M. Casselman, S. R. LaPan, R. G. Werner, and A. Schiavone. 2007. Development, implementation, and evaluation of an international muskellunge management strategy for the upper St. Lawrence River. Environmental Biology of Fishes 79: 111-123.

Holm, E., N. E. Mandrak, and M. E. Burridge. 2009. The ROM Field Guide to the Freshwater Fishes of Ontario. Royal Ontario Museum, Toronto. 462 pages.

Hoyle, J. A., J. N. Bowlby, T. B. Johnson, B. J. Morrison, C. M. Brousseau, and R. G. Randall. In press. Bay of
Quinte fish populations: the influence of nutrient levels and invasive species on community structure. Aquatic Ecosystem Health and Management.

Mandrak, N. E. 1989. Potential invasion of the Great Lakes by fish species associated with climatic warming. Journal of Great Lakes Research 15: 306-316.

Scott, W. B., and E. J. Crossman. 1998. Freshwater Fishes of Canada. Includes Authors' Comments, 1998. Galt House Publications, Oakville, Ontario. 966 pages. (Originally published in 1973, Fisheries Research Board of Canada Bulletin 184.)

Received 3 August 2010

Accepted 18 March 2011

\section{ADDENDUM}

Since the acceptance of this paper the following eight additional Chain Pickerel records have been documented. All fish were caught by commercial fishers in hoop net gear.

TABLE 1. Chain pickerel caught in Ontario, 2011.

\begin{tabular}{lcccccccc}
\hline \hline & \multicolumn{7}{c}{ Fish } \\
\cline { 2 - 9 } & 1 & 2 & 3 & 4 & 5 & 6 & 7 & 8 \\
\hline Latitude & 43.951 & 44.200 & 43.969 & 44.187 & 44.218 & 44.187 & 44.187 & 44.187 \\
Longitude & -77.296 & -76.345 & -77.001 & -76.625 & -76.546 & -76.625 & -76.625 & -76.625 \\
Date of capture & $16-$-Sep-10 & $14-$-Apr-11 & $27-$ Apr-11 & $2-$-May-11 & $7-$-May-11 & $13-$ May-11 & $13-$ May-11 & $13-$ May-11 \\
Total length (mm) & 575 & 636 & 435 & 535 & 615 & 647 & 625 & 506 \\
Fork length (mm) & 548 & 591 & 407 & 511 & 574 & 598 & 584 & 467 \\
Round weight (g) & 1381 & 2023 & 573 & 1357 & 1640 & 2009 & 1568 & 936 \\
Sex & $\mathrm{F}$ & $\mathrm{F}$ & $\mathrm{M}$ & $\mathrm{F}$ & $\mathrm{M}$ & $\mathrm{M}$ & $\mathrm{F}$ & $\mathrm{M}$ \\
\hline \hline
\end{tabular}

